\title{
THE FIRST CREMATION TRACES \\ IN THE ENEOLITHIC PERIOD NORTH OF THE CARPATHIAN MOUNTAINS
}

\begin{abstract}
Wilk S. and Szczepanek A. 2017. The first cremation traces in the Eneolithic period north of the Carpathian Mountains. Sprawozdania Archeologiczne 69, 353-371.

The subject of this article is the first eneolithic cremation burial in south-eastern Poland which was discovered on the cemetery of the Lublin-Volhynia culture at site 2 in Książnice, voiv. świętokrzyskie. Grave 14 was unearthed while exploring the western part of the necropolis in August 2012. The burial pit, $122 \times 75 \mathrm{~cm}$, was shaped like a rectangle with rounded corners, elongated along the north-south axis. In the southern part of the grave, at the depth of 40-45 cm, a concentration of charred human bones was found belonging to an individual at the age of maturus. The grave goods consist of two clay vessels (a pear-shaped cup with knobs on the larger bulge of its body, and a miniature pot with a gooseneck profile and notched spout) and twelve flint artefacts. The analyzed burial is another example of the intense cultural influences of the Hunyadihalom-Lažňany horizon to the late younger Danubian communities inhabiting Lesser Poland at the turn of the $5^{\text {th }}$ and 4 th millennia BC.
\end{abstract}

Keywords: Copper Age, burial rites, cremation, Lublin-Volhynia culture, Carpathian Basin, Hunyadihalom-Lažňany horizon, Lesser Poland

Received: 01.03.2017; Revised: 18.04.2017; Accepted: 14.06.2017

\footnotetext{
* Karkonosze Museum, Jana Matejki 28, 58-50o Jelenia Góra, Poland; archeowolf@wp.pl

** Institute of Archaeology and Ethnology, Polish Academy of Sciences, Sławkowska st. 17, 31-016 Kraków, Poland; anita.szczepanek@uj.edu.pl
} 


\section{INTRODUCTION}

Research on the burial ritual of the younger Danubian cultures on Polish territory has remained a focus of attention for archaeologists for nearly 100 years. Despite the relatively small amount of sources we can rather accurately characterize the principles of the burial rituals of Lengyel and Polgar societies living on the territory between the Odra and Bug rivers, and between the Baltic Sea and the Carpathian and Sudety Mountains. The most important practice is inhumation, with the prevailing orientation of pits along the N-S axis with slight variations, with skeletons arranged with their skull to the south; and, in the Brześć Kujawski culture, Jordanów, Lublin-Volhynia cultures, and the Wyciąże-Złotniki group with clearly different arrangements of bodies, depending on their sex (the left side - female, the right side - male), and various amounts of prestigious burial goods made of copper, flint, horn and shells (Czekaj-Zastawny 2009; Grygiel 2008; Seger 1906; Gediga et al. 2012).

Among younger Danubian societies the Lublin-Volhynia culture, which flourished in south-eastern Poland and western Ukraine in the second half of the $5^{\text {th }}$ and the first half of the $4^{\text {th }}$ millennium BC, is of particular importance. Burial rituals of this group belong to the best recognized in the entire Eneolithic on Polish lands. As a result of many years of research on the problems related to burial practices of the Lublin-Volhynia culture, a monograph on the burial ritual of this culture was published by Anna Zakościelna in 2010, containing a compendium of knowledge about the burial practices, anthropology and characteristics of artifacts unearthed in over 150 Lublin-Volhynia graves (Zakościelna 2010).

Nowadays, the best studied cemetery of the Lublin-Volhynia culture is the necropolis at site 2 in Książnice, Świętokrzyskie province, with its 17 certain and 4 probable burials, which have been systematically excavated by the author of this article since 2001.

The cemetery, located on top of a small hill in the eastern part of the Pińczów Hummock (Fig. 1), consists of two burial areas, clearly separated by several dozen meters: one eastern, and one western, together comprising an oval, elongated along the NW-SE axis. The eastern part, consisting of 8 well-preserved burials, is rectangular in shape, elongated on the N-S axis. The western part consists of 8 burials, which are more poorly preserved and more chaotically located. Between the western and eastern areas, lies grave 17 (Fig. 2; Wilk 2016; Wilk and Diakowska-Kufel 2016).

The relics of sepulchral practices discovered in Książnice are not vastly different from rules of rituals found on other cemeteries of the Lublin-Volhynia culture. In most cases, the burials are skeletal, pits are oriented on the N-S or NW-SE axis, and the dead are equipped with similar sets of burial goods, usually consisting of several (mostly, 2-3) vessels, and - depending on the sex - copper ornaments or flint and copper tools (Wilk 2004; 2006; 2014). In addition, there were two cenotaphs (graves 6 and 9) discovered on the cemetery, and a partial burial with a copper axe of the Şiria type (grave 3).

Only one grave widely differs from the described norm because the remains of the deceased found there had been cremated. 

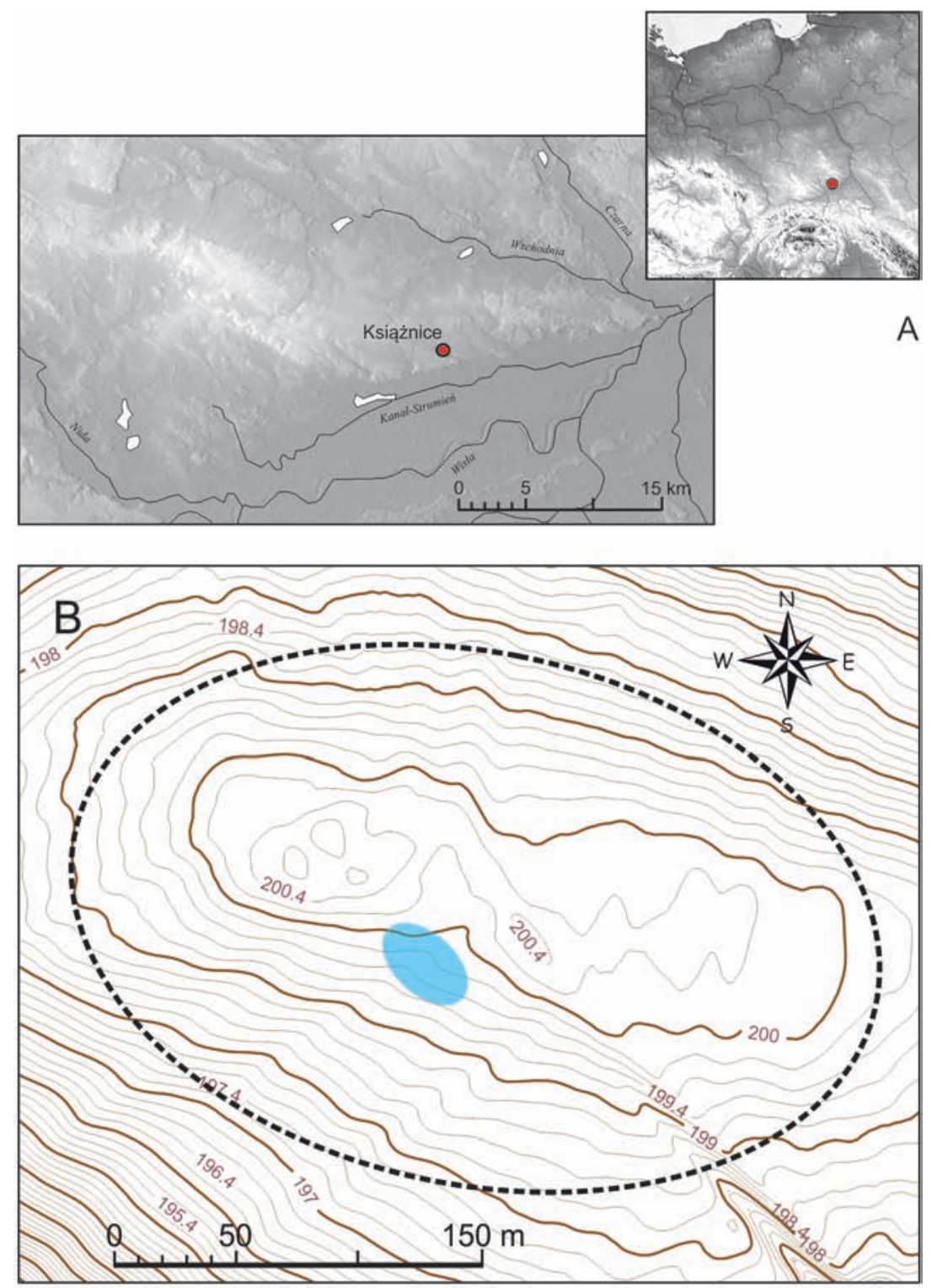

\section{LEGEND \\ - estimated area of the site 2 in Książnice \\ - area of the cemetery of the Lublin-Volhynian culture}

Fig. 1. Location of the Lublin-Volhynian culture cemetery at site 2 in Książnice, Świętokrzyskie province 


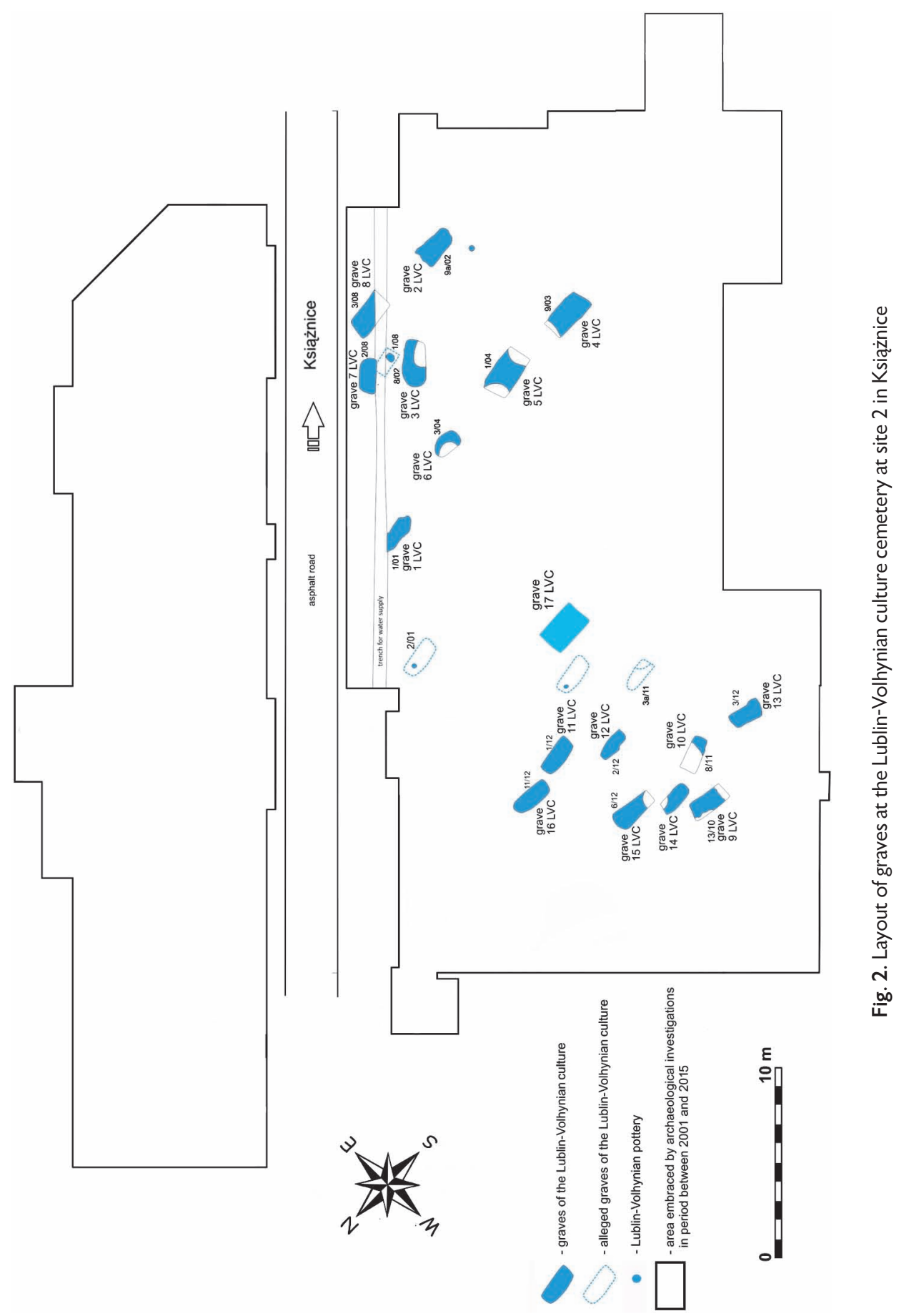



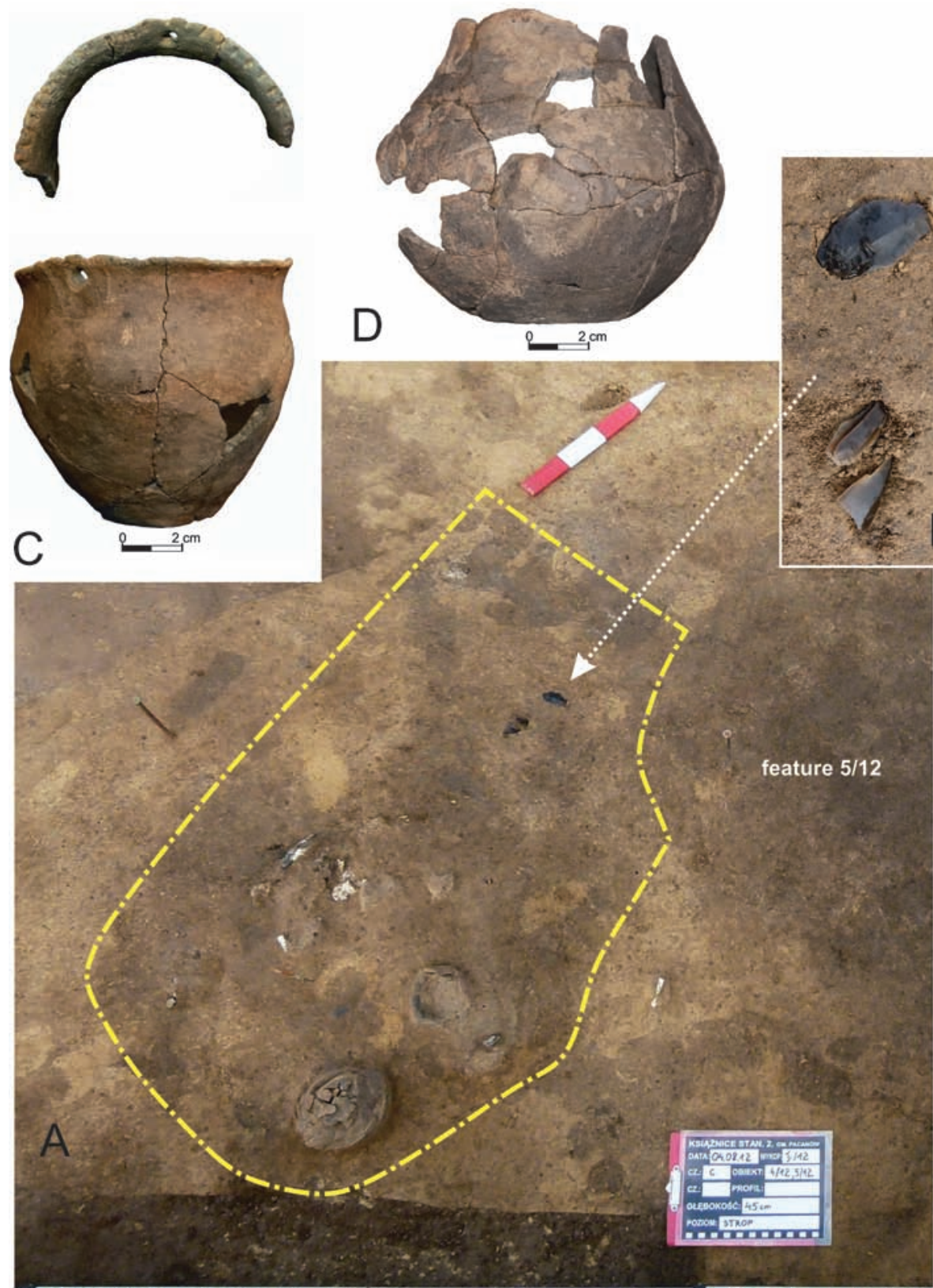

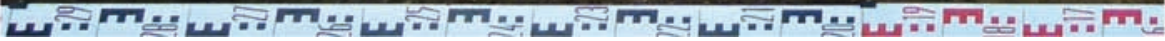

Fig. 3. A - Grave 14 at a depth of $45 \mathrm{~cm}$; B - Close up of the location of flint artefacts in the north part of the burial pit; C - Pear-shaped cup; D - Miniature gooseneck pot, photo by S. Wilk 

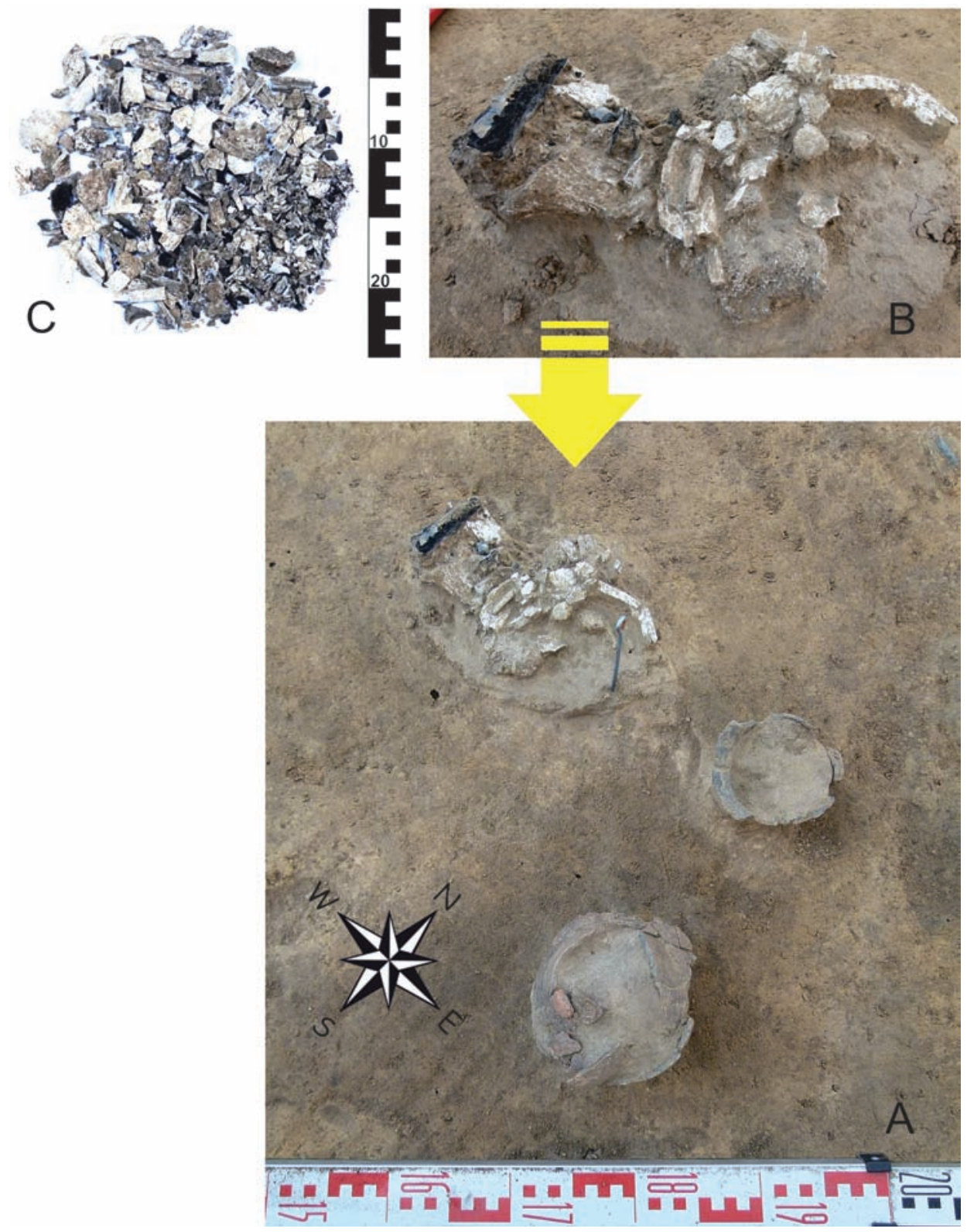

Fig. 4. A - Grave14, plan at the level of the burning bones, at a depth of $45-50 \mathrm{~cm}$; B - close up of the burning bones; C - burning bones after dissection, A, B - photo by S. Wilk; C - photo by A. Szczepanek 


\section{GRAVE 14 AND ITS BURIAL GOODS}

\subsection{Description of the burial}

Grave 14 (feature 4/2012) was unearthed while exploring the western part of the necropolis in August 2012. The roof of the feature was visible at the depth of $40 \mathrm{~cm}$ within part C of trench I/12. The burial pit, $122 \times 75 \mathrm{~cm}$, and with a fill consisting of grey and brown soil, was shaped like a rectangle with rounded corners, elongated along the northsouth axis. To the north-east, the pit was damaged by feature 6/12 of the Funnel Beaker culture (Fig. 3).

In the southern part of the grave, at the depth of 40-45 cm, a concentration of charred human bones, belonging to an individual at the age of maturus, was found. Single charred

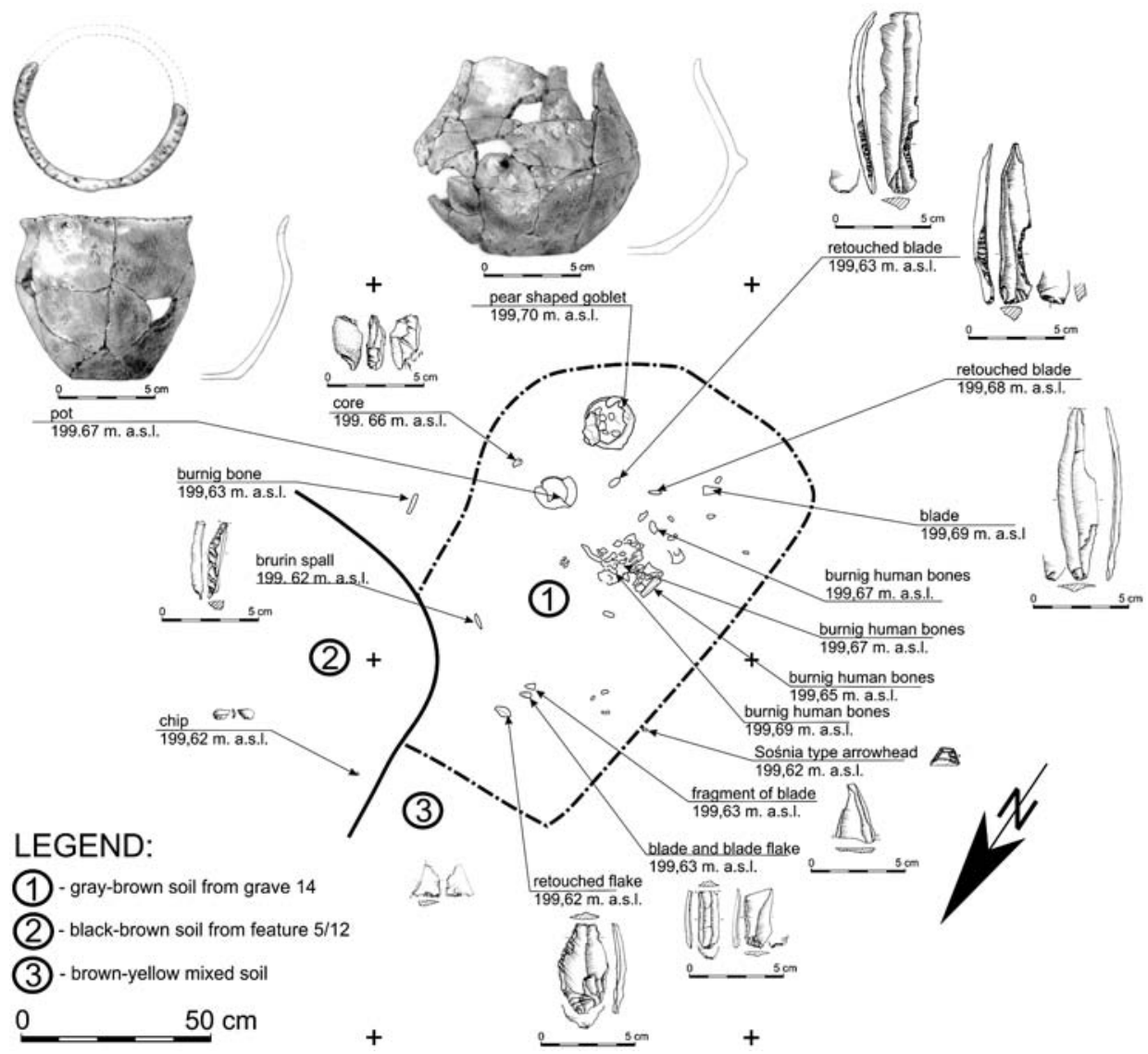

Fig. 5. A - Grave 14, plan with grave goods at a depth of $45-50 \mathrm{~cm}$, drawing by S. Wilk 
bones were also found in the close vicinity of the grave, and its northern part (Fig. 4: A). In the main concentration, there were burnt bones exhibiting black and white color (Fig. 4: B), among which it was possible to distinguish, in some places, long bones and bones with flat surfaces (cranial bones).

Grave goods consist of two clay vessels and twelve flint artefacts. The vessels (a pearshaped cup with knobs on the larger bulge of its body, and a miniature pot with a gooseneck profile and notched spout) were found in the southern part of the burial pit, ca 15$20 \mathrm{~cm}$ to the east and to the south of the concentration of burnt bones (Fig. 5). As regards the flint artefacts, the three biggest specimens were discovered in the southern part of the pit, several dozen centimeters to the south of the concentration of burnt bones. Two chocolate flint blades with retouched notches, which were found stuck perpendicularly in the ground, while there was another chocolate flint blade lying flat several dozen centimeters to the west. Several centimeters to the east of the miniature pot, a small core made of erratic flint was found. The remaining flint artefacts were unearthed in the northern part of the pit. Separately found, closer to the eastern edge of the pit, there was a burin spall made of Świeciechów flint, while a retouched flake, a blade, a flake with proportions of a blade, and a fragment of a blade (all made of chocolate flint) were found in the concentration, ca $20 \mathrm{~cm}$ off the northern edge of the burial pit. The only arrowhead of the Sośnia type, found in this assemblage and made of chocolate flint, was unearthed near the western edge of the burial pit (Fig. 5).

\subsection{Description of burial goods}

\subsubsection{Pottery}

1. Miniature gooseneck pot, with the largest circumference in the upper part of the vessel and a short, leaning to the outside neck crowned with a notched spout (fig. 3: C, 6: A). Fragmentarily preserved. Dimensions: height $85 \mathrm{~mm}$, spout diameter: $87 \mathrm{~mm}$, bottom diameter: $43 \mathrm{~mm}$, thickness of walls: $3-4 \mathrm{~mm}$. The vessel was made of clay tempered with grog and fine sand. The outer surface is gray, and gray and beige in color. The inner surface is gray and beige in color. In the spot where the spout protrudes slightly, there is a horizontal hole in the wall of the vessel. Probably, the pot had two such holes.

2. Pear-shaped cup, decorated with two horn-like knobs (only one has been preserved) where the circumference of the vessel's body is the biggest (Fig. 3: D, 6: B). The vessel is only fragmentarily preserved. Dimensions: height: $110.1 \mathrm{~mm}$; spout diameter: ca $90 \mathrm{~mm}$, bottom diameter: $58 \mathrm{~mm}$, thickness of walls: $3-5 \mathrm{~mm}$. The vessel was made of clay tempered with grog and fine sand. The outer surface is gray in color, and in some places - orange. The inner surface is gray and beige.

The bad condition of vessel from the grave 14 is the result of postdeposition processes. 

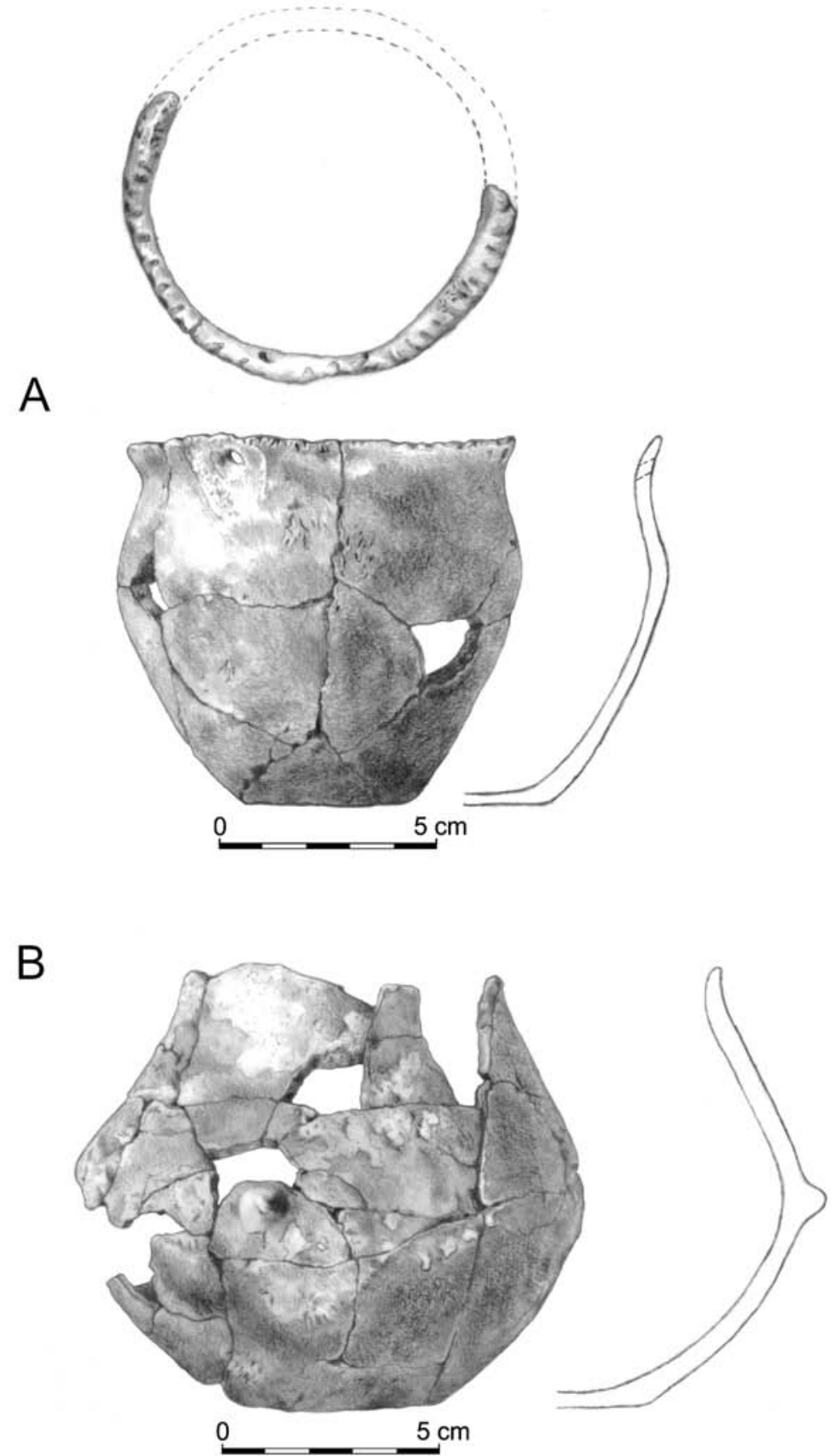

Fig. 6. Pottery from grave 14, drawn by K. Kielijańska 


\subsubsection{Flints}

A

B

C
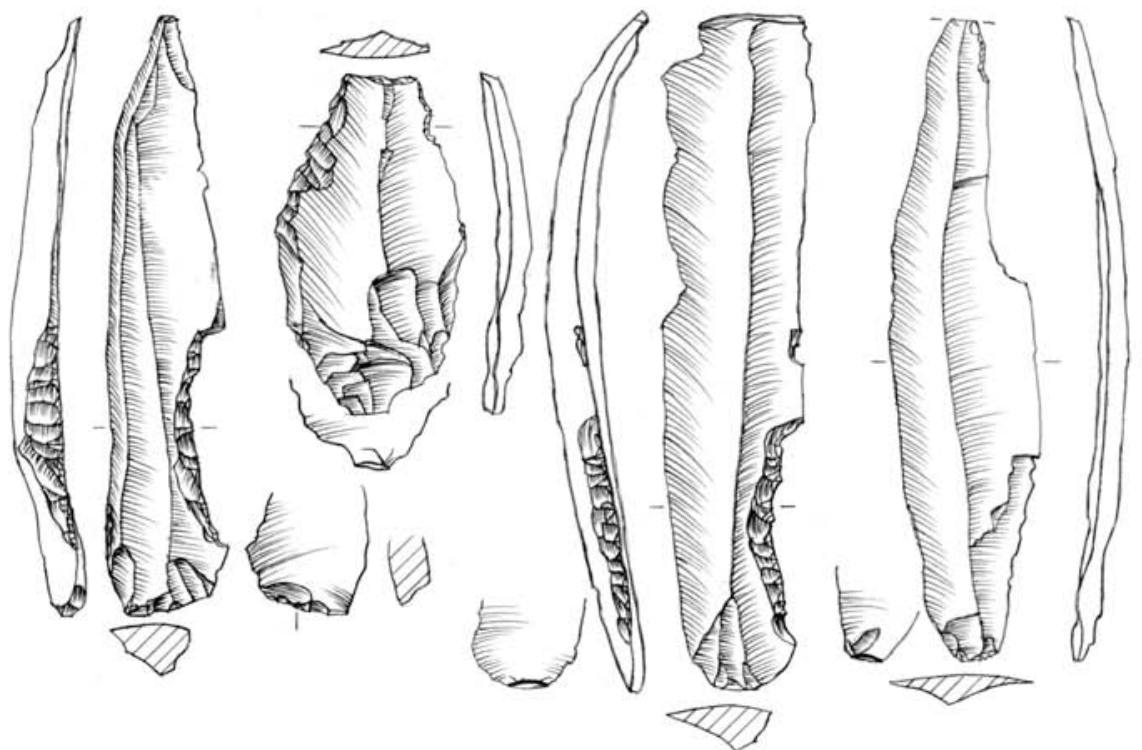

E

$\mathrm{F}$

G

$\mathrm{H}$

$J$
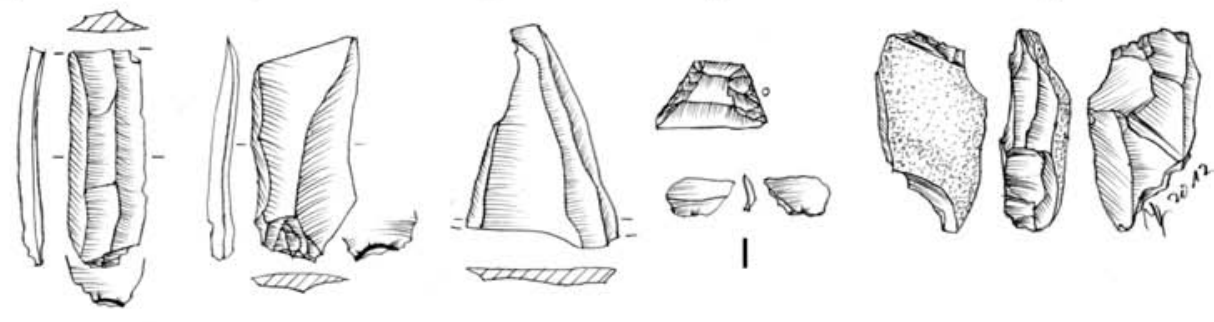

$\mathrm{K}$
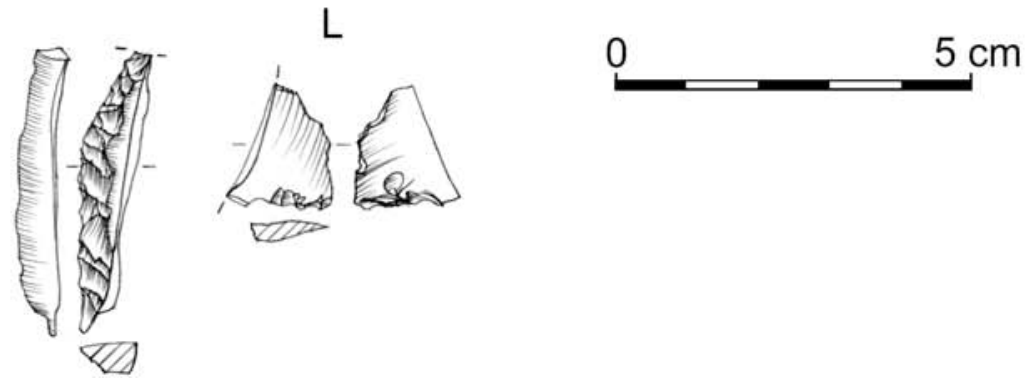

Fig. 7. Flint artefacts from grave 14 , drawn by J. Libera 


\begin{tabular}{|c|c|c|c|c|c|c|c|c|c|c|c|c|}
\hline 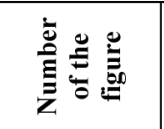 & $\begin{array}{l}\ddot{0} \\
\ddot{r} \\
\dot{a j}\end{array}$ & 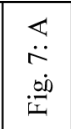 & $\begin{array}{l}m \\
\ddot{r} \\
\stackrel{b}{\dot{b}}\end{array}$ & 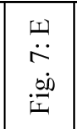 & $\begin{array}{l}m \\
\ddot{r} \\
\stackrel{\infty}{\dot{\phi j}}\end{array}$ & 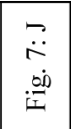 & 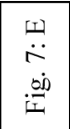 & $\begin{array}{l}\dot{0} \\
\ddot{\sim} \\
\text { b. } \\
\dot{a}\end{array}$ & 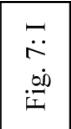 & 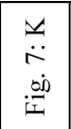 & 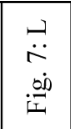 & 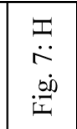 \\
\hline 突 & 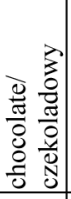 & 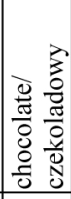 & 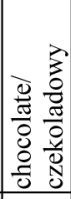 & 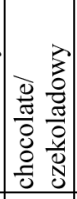 & 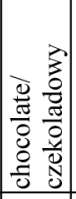 & 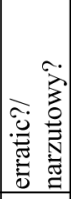 & 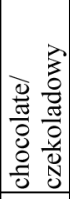 & 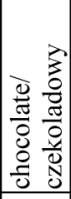 & 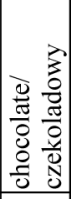 & 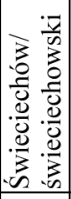 & 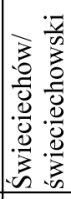 & 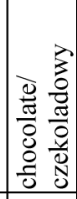 \\
\hline 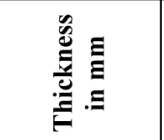 & $\stackrel{\circ}{f}$ & $\tilde{6}$ & $\therefore$ & ते & $\begin{array}{l}\because \\
\stackrel{n}{*}\end{array}$ & $\approx$ & $\begin{array}{l}\infty \\
i\end{array}$ & $\vec{m}$ & $\stackrel{\cong}{=}$ & $\vec{n}$ & $\stackrel{\circ}{\circ}$ & $\hat{i}$ \\
\hline 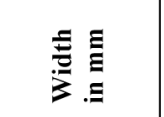 & $\begin{array}{l}\text { ㅇ. } \\
\text { i }\end{array}$ & $\begin{array}{l}\text { ㅇ. } \\
\text { i }\end{array}$ & $\begin{array}{l}\text { ㅇ. } \\
\text { ì }\end{array}$ & $\stackrel{n}{\tilde{i}}$ & $\begin{array}{l}0 \\
\dot{\sigma}^{\circ}\end{array}$ & $\begin{array}{l}0 \\
\text { in }\end{array}$ & $\stackrel{\sim}{0}$ & $\begin{array}{l}0 \\
\stackrel{0}{n}\end{array}$ & $\ddot{\circ}$ & $\stackrel{n}{\sim}$ & $\vec{n}$ & $\bar{a}$ \\
\hline 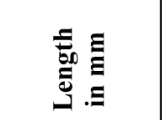 & $\begin{array}{l}0 \\
\infty \\
\infty\end{array}$ & $\stackrel{0}{\infty}$ & $\begin{array}{l}\circ \\
\dot{a}\end{array}$ & $\begin{array}{l}\text { i } \\
\text { in }\end{array}$ & $\frac{\circ}{f}$ & $\begin{array}{l}n \\
\infty \\
\infty \\
\sim\end{array}$ & $\begin{array}{l}\text { on } \\
\text { on }\end{array}$ & $\frac{n}{n}$ & in & $\begin{array}{l}\circ \\
\stackrel{q}{q}\end{array}$ & $\frac{n}{\sim}$ & $\begin{array}{l}\circ \\
\stackrel{1}{n}\end{array}$ \\
\hline 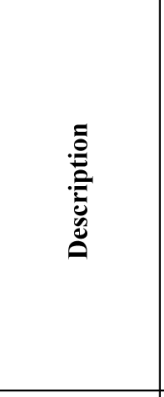 & 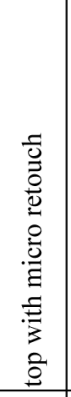 & 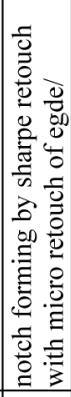 & 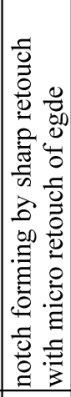 & 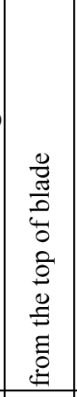 & 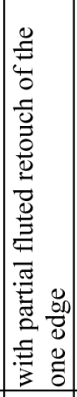 & 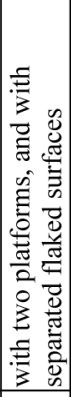 & & & & & & 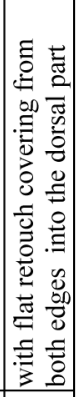 \\
\hline$\stackrel{\Xi}{ٍ}$ & $\frac{\pi}{0}$ & $\begin{array}{l}\frac{5}{0} \\
\frac{0}{3} \\
\frac{0}{0} \\
\frac{0}{0} \\
\frac{\pi}{0} \\
\frac{0}{0}\end{array}$ & $\begin{array}{l}\frac{0}{3} \\
\frac{0}{3} \\
\frac{0}{0} \\
\frac{0}{0} \\
\frac{0}{0}\end{array}$ & 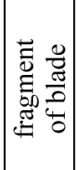 & $\frac{\mathscr{y}}{\tilde{G}}$ & : & 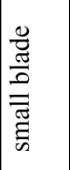 & $\begin{array}{l}\frac{9}{\pi} \\
\stackrel{\frac{\pi}{1}}{\frac{d}{0}} \\
\frac{\pi}{0}\end{array}$ & ్ㅠㅇ & $\begin{array}{l}\overline{\bar{\sigma}} \\
\text { की } \\
\text { 志 } \\
\text { ప }\end{array}$ & 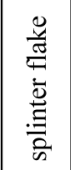 & 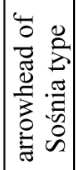 \\
\hline 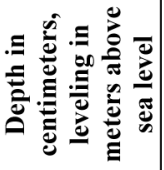 & 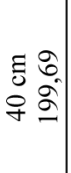 & 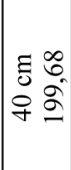 & 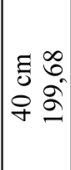 & 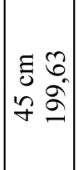 & 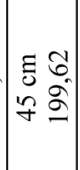 & 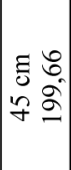 & 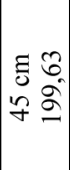 & 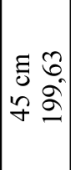 & 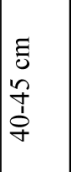 & $\begin{array}{l}\Xi \\
0 \\
\text { \& }\end{array}$ & 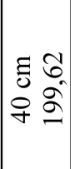 & 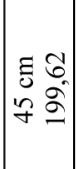 \\
\hline 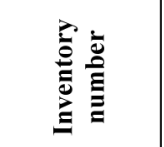 & $\frac{\substack{2 \\
\frac{2}{2}}}{\frac{1}{2}}$ & $\frac{\substack{0 \\
\frac{m}{2}}}{2}$ & $\frac{\substack{1 \\
\frac{1}{2}}}{3}$ & $\frac{\sqrt{3}}{3}$ & $\frac{\sqrt[3]{3}}{3}$ & $\frac{\substack{n \\
\frac{1}{2}}}{\frac{1}{2}}$ & 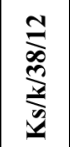 & $\frac{\mathfrak{3}}{3}$ & $\frac{\substack{1 \\
\frac{3}{2}}}{\frac{1}{2}}$ & $\frac{\sqrt[3]{2}}{\frac{1}{3}}$ & $\frac{\sqrt[n]{n-3}}{\frac{3}{3}}$ & $\frac{\frac{\sqrt[n]{n}}{7}}{\frac{7}{7}}$ \\
\hline 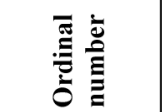 & - & $\sim$ & $m$ & + & in & 0 & $r$ & $\infty$ & $a$ & 으 & $=$ & $\simeq$ \\
\hline
\end{tabular}




\subsection{Analysis of the grave inventory}

In the Lublin-Volhynia culture the closest analogy to the gooseneck vessel from grave 14 can be found in the gooseneck vessel with two perforated protrusions on the spout from grave II from site 5 in Jaszczów (Kowalczyk 1950, tabl. II, fig. 3; Zakościelna 2010, 261, tabl. XXI: 4) and a specimen from pit t at site 7 in Las Stocki (Kadrow, Zakościelna 2000, fig. 22: c). Similar, but slightly slimmer and equipped with two handles, specimens come from graves: 390 at the "Grodzisko" I site in Złota (Sałacińska and Zakościelna 2007, fig. 12: 1) and 101 at the "Grodzisko" II site in the same village (Sałacińska and Zakościelna 2007, fig. 20:7). On the other hand, from grave 4 at site 2A in Strzyżów comes a small gooseneck pot with four horn-like knobs on the most bulging part of its body (Gurba and Kutyłowski 1970, pl. 152: 9). Two sherds of vessels with horizontal holes below their spouts were found at site 1D in Strzyżów (Kadrow 1989, 29, fig. 8: 6).

The research conducted on the cemetery in Książnice yielded four specimens of gooseneck pots with handles and notched spouts. Three larger vessels were found in graves 2, 4 and 5 (Wilk 2004, fig. 4B, fig. 7C:2; 2006, fig. 8B), while, the fourth - the smallest - comes from an unpublished grave 12 .

In the materials of the Wyciąże-Złotniki group, no identical vessel has been unearthed to date. However, we know some examples of gooseneck pots, including one miniature vessel decorated with four knobs on the most bulging part of its body, which was found in grave 8 at the cemetery in Kraków Nowa Huta-Wyciąże (Kozłowski 1971, tabl. IX: 3).

Various types of pots with notched spouts, sometimes decorated with knobs on their most bulging part of body, constitute a popular form of vessels in the HunyadihalomLažňany horizon. Stanislav Šiška described them as small vessels shaped like pots with short cylindrical necks - Type Ia (Šiška 1972, 126, 131).

We know them, among others, from grave 16 at the cemetery of Šebastovce, (Šiška 1972, tabl. VI:2), graves 2, 10, 15 and 16 at the cemetery of Barca (Šiška 1972, tabl. XII:7, Abb. 32: 2, 3, tabl. XI:7), and graves 4 and 14 at the cemetery Malé Zalužice - Lažňany (Budinský-Krička 1964, image 5:4, image 7:5). Moreover, a sherd of a pot which had a similar profile and a small handle protruding above the rim, and a notched spout was found in the settlement of Tiszalúc (Patay 2005, tabl. 25:1, 48: 5).

Cups, side by side with vessels shaped like flower pots, are the most popular type of pottery in the Lublin-Volhynia culture (Zakościelna 2010, 120, 124). Covered with white paint, or unpainted, they occur on many sites, including graves 1 and 2 from site 5 in Jaszczów (Zakościelna 2010, tabl. XX: A3, XXI: 7), in graves 1, 2, 4, 6, 7, 8, 9, 10 on site 16 in Krasne Kolonia (Zakościelna 2010, tabl. XXIII: 1-2, tabl. XIV: 1-4, tabl. XXVI: 9, tabl. XXVIb: 18-19, tabl. XXVIII: 1, 2, 4, tabl. XXVIIIb: 7, 8, 10, tabl. XXIX: 2-6, tabl. XXXIIa: 4, 7, 8, tabl. XXXIIc: 13-16), as well as in grave 390 on the Grodzisko I site in Złota (Sałacińska and Zakościelna 2007, fig. 12: 2). However, pear-shaped cups of medium size and with horn-like knobs on the most bulging part of their bodies are rare. In larger amounts, they 
have only been discovered in graves 2 and 6, and 11, 12 and 17 (unpublished) at the cemetery in Książnice (Wilk 2004, fig. 4: B2; 2006, fig. 14: B,C), and also in graves 101, 121 and 122 on site Grodzisko II in Złota (Sałacińska and Zakościelna 2007, fig. 20: 2, 4, 11, fig. 25: 2, fig. 29: 7). Slightly bigger specimens come from graves 4 and 7 at the cemetery in Krasne Kolonia (Zakościelna 2010, tabl. XXVIc: 26; XXIXb: 13).

While analyzing the flint inventory found in grave 4, in comparison to other sepulchral assemblages of the Lublin-Volhynia culture, their size and diversity is noteworthy. The grave yielded 12 artefacts, representing as many as 9 categories of artefacts (Table. I; Fig. 7). Twelve or more flint artefacts occurred in only three cases: in grave 1/1961 at site IA in Strzyżów, and in graves 4 (18 specimens) and 5 (12 specimens) at site 2 in Książnice (Zakościelna 2010, tab. 34; Wilk 2004, table 2; Wilk 2006, table 2).

Looking at the structure of the discussed assemblage, it must be observed that it differs from other assemblages of burial goods of the Lublin-Volhynia culture because it contains rare types of artefacts: a burin spall, two blades with retouched notches and an arrowhead of the Sośnia type.

To date, blades with retouched notches have occurred only at site 7 in Las Stocki (Zakościelna 1996, tabl. XIV:22, tabl. XXI: 2). While, grave 1 in Zubków yielded a notched blade of Volhynian flint, formed using continuous fluted retouch on both edges (Zakościelna 2010, tabl. LXXXIXa: 6).

The burin spall from grave 14 in Książnice is the only one of this type of find discovered in the sepulchral context of the Lublin-Volhynia culture. Likewise, the arrowhead of the Sośnia type, unearthed near the western edge of the burial pit, is very rare. Four arrowheads of this type were found in the assemblage of artefacts discovered in the north-western part of grave 4 in Książnice and consisting of 16 artefacts (including, 12 trapezoids of chocolate flint), which was ultimately interpreted as a quiver with arrows (Wilk 2004, fig. 7: 16-18).

Apart from the cemetery in Książnice, a single arrowhead of the Sośnia type was found in feature 1/83 at site C in Gródek (Zawiślak 2013, tabl. LIX: 3).

While investigating the location of individual artefacts in the burial pit, it can be concluded that its creators relied on the same logic as those of more traditional skeletal burials while arranging the burial space. Both vessels were found in the southern part of the pit, in the place corresponding to the customary positioning of vessels in male graves - at the height of the chest and before the skull (e.g., in graves 1, 4, 5, 17 from the cemetery in Książnice; Wilk 2004, fig. 3A, 7A; Wilk and Diakowska-Kufel 2016, fig. 3). Some of the flint artefacts were also found in the southern part of the pit, in the place, in which - in the case of a classic skeletal grave - the skull should be lying. This fact, as well as the character of burial goods, among which 12 flint artefacts, allows us to make a very probable assumption that an adult male was buried in grave 14 . 


\subsection{Anthropological analysis}

Cremated bones were mechanically divided during exploration. Anthropological analysis was done by Anita Szczepanek.

Inventory: KS/15/12. Bones strongly and evenly burnt, cream-beige in colour, weight $2 \mathrm{~g}$. The preserved elements include scarce, small fragments of bones from cranial vault (the largest ones 1,3 x 1,2 cm). Inventory: KS/25/12. Bones strongly and unevenly burnt, creambeige or black in colour, weight $3 \mathrm{~g}$. The preserved elements of post cranial skeleton include small fragments of diaphyses and epiphyses of long bones (the largest ones 1,9 x 1,6 cm).

Upper part of the grave pit. Bones strongly and unevenly burnt, cream-beige or black in colour, weight $81 \mathrm{~g}$. The preserved elements of skeleton include fragments of cranial bones (the largest ones $3 \times 3 \mathrm{~cm}$ ) and pieces of diaphyses (the longest ones $5,3 \mathrm{~cm}$ ) and epiphyses of long bones as well as parts of ribs and scapular spine.

Grave pit. Bones strongly and unevenly burnt, cream-beige or black in colour (Fig. 4: $\mathrm{B}, \mathrm{C}$ ), weight $233 \mathrm{~g}$. The preserved elements of cranium include fragments of cranial vault (the largest ones $4 \times 3 \mathrm{~cm}$ ), sutures partially fused, and fragments of petrosal part of temporal bone. Facial bones are represented by fragment of mandibular body with alveoli and roots of permanent teeth. Elements of post cranial skeleton comprise numerous fragments of long bones epiphyses and diaphyses (the longest ones $5,7 \mathrm{~cm}$ ) as well as parts of costae, bodies of vertebrae and elements of pelvis. On the basis of the cranial suture obliteration, the age at death of this individual was established as Maturus, the sex was not determined.

Additionally at a depth of 40-45 cm slightly burnt small fragments of human bones ( $1 \mathrm{~g}$ ) and parts of animal teeth (cattle) were found although the animal bones could have got into the feature accidentally.

The anthropological analysis enabled to establish the colour and the degree to which the bones has been burned as well as to determine the age at death of this individual (Fairgrieve 2008). The determination of the sex according to anthropological criteria was not possible due to the lack of diagnostic skeletal fragments. The cream-beige colour observed in the analysed material suggest that the bones were heated to more than $800^{\circ} \mathrm{C}$ (Fairgrieve 2008), which means that the temperature in the place where they were burned might have reached $1000-1200^{\circ} \mathrm{C}$. This temperature was probably achieved during cremation on a pyre (Piontek 1976; 2002). Simultaneously, some fragments of the skull and also the long bones of the diaphyses are black in colour indicating a lower burning temperature, so the temperature within the pyre was differentiated. The total weight of the burned bones is $320 \mathrm{~g}$ and it is lower than the experimentally achieved mass of cremated remains that is $2284 \mathrm{~g}$ (1735-3001 $\mathrm{g}$ ) in the case of male burials and $1616 \mathrm{~g}$ (1227-2216 $\mathrm{g}$ ) in female burials (McKinley 1994). 


\subsection{Dating of grave 14}

We have no radiocarbon dating from this grave, and therefore its chronology is determined by the interpretation of the data coming from the typological analysis of the artefacts, the dating of the entire cemetery of the Lublin-Volhynia culture on site 2 in Książnice, and the chronology of the occurrence of cremation graves on the neighboring territories.

Pear-shaped cups occur practically during every stage in the development of the Lublin-Volhynia culture, and as a vessel form they are of no chronological significance. However, the tendency to ornament vessels with horn-shaped knobs on the circumference of vessels' bodies, which is observed on vessels from Książnice, Złota and Krasne-Kolonia, together with the knowledge of the absolute chronology of these necropolises (Sałacińska and Zakościelna 2007, tabela 2; Wilk 2016, fig. 11; Zakościelna 2010, tab. 6), makes us relate specimens decorated in this way to the younger stage in the development of the Lublin-Volhynia culture.

In the case of gooseneck pots with notched spouts, the problem is more complicated. Zakościelna and Kadrow, relying on the assemblages from site 7 in Las Stocki and site 6 in Wąwolnica, related the presence of such vessels to phase II of the Lublin-Volhynia culture (Kadrow and Zakościelna 2000, 214, figs. 22-24; Zakościelna 2006, 82, fig. 3). Bearing in mind the genetic connections between the Rzeszów phase of the Malice culture and the early stage of the Lublin-Volhynia culture, which are emphasized by both authors, it must be presumed that the observed custom of decorating vessel spouts with a fingerprint motif, as well as with notches, has its origin in the Malice culture. The question, however, remains how to explain the flourishing of this type of ornamentation in phase III, in which gooseneck pots decorated with fingerprints or notches constitute a large percentage of pottery inventories (e.g., sites 3 and 10 in Łańcut; Gruszczyńska and Mitura 2002, 50-51; Kadrow and Kłosińska 1989, 12, fig. 7), at the defense settlement of Bronocice (Kruk and Milisauskas 1985, 55-57), at site 2 in Książnice (Wilk 2004, fig. 4B:3, fig. 7C:2; 2006, fig. 8B), and they also occur in the Wyciąże-Złotniki group (Kozłowski 1971, table VII: 4). Is this an effect of natural development of such ornamentation in the Lublin-Volhynia culture, or perhaps - like the form of gooseneck pots themselves - it has an entirely different provenance, related to the trans-Carpathian influences of the Hunyadihalom-Lažňany horizon (Kruk and Milisauskas 1985, 85; Kaczanowska 2009, 80).

In summary, as long as we do not have radiocarbon dating, the most reliable way of dating grave 14 is to relate it to the chronology of the entire cemetery at site 2 in Książnice.

At the moment, on the basis of the analysis of imported copper artefacts and the presence of pottery belonging to the Hunyadihalom-Lažňany horizon, and the basis of the results of calibration of radiocarbon datings for graves 7 and 8 , it seems that the necropolis functioned at the turn of the $5^{\text {th }}$ and $4^{\text {th }}$ and early in the $4^{\text {th }}$ millennium BC, most probably between 4030-3830 BC (Wilk 2016, 24). However, while looking at the number of unearthed burials, the real period of using the cemetery should not have exceeded 80 to 100 
years (Wilk 2016, 23; Furmanek and Mozgała-Swacha 2017, 181). Such a chronology of the site in Książnice corresponds well to the new data about the absolute chronology of the Copper Age in the Carpathian Basin, and the proposal of a much earlier dating of the Hunyadihalom-Lažňany horizon than previously assumed, going back to 4200/4000/39503800/3750 BC, (Raczky and Siklósi 2013, 569-570, fig. 6, 7; Brummack and Diaconescu 2014, fig. 12, fig. 13, 252). If we add to this that the vast majority of instances of cremation burial practices in this part of Europe are associated with the horizon HunyadihalomLažňany, the aforementioned argument becomes even more valid.

\section{THE CREMATION BURIAL PRACTICE IN THE COPPER AGE IN THE CARPATHIAN BASIN AND WESTERN UKRAINE}

In the second half of the $5^{\text {th }}$ and at the beginning of the $4^{\text {th }}$ millennium $\mathrm{BC}$, corresponding to the period when the Lublin-Volhynia culture was developing on the areas covered by the present-day south-eastern Poland and western Ukraine, in the Carpathian Basin and the north edge of the Carpathian Mountains, some of the societies living there used biritual burial practices, consisting of inhumation and cremation of the body, and two types of burial: a pit burial, and a cremation (urn) burial (Fig. 8).

The beginnings of cremation burial in Central Europe date to the Mesolithic (GilDrozd 2010; Kośko and Videiko 1995). On the territory of the Carpathian Basin, which is of particular interest to us, this type of burial was used with varying intensity from the beginnings of the Neolithic, and lasted until the late Copper Age (Lichter 2001, tabelle 24, abb. 168; Nevizansky 1985, 258; Šutekova 2007, 6-9).

Related to the early Copper Age, evidence of the use of cremation come from a necropolis of the Tiszapolgár culture in the villages of Lúčky (8 graves, Nevizánsky, 1984, 264), Tibava (graves 3/55, 3, 6, 15/56; Šiška 1964, 339-340) and Vel'ke Raškovce (grave 22; Vizdal 1977, 46-47). In the Bodrogkeresztúr culture, instances of cremation have occurred twice, in grave 29 on the Jászladány cemetery, and in grave 4 on the Fényeslitke cemetery (Nevizansky 1984, 279). Both in the case of Tiszapolgár and the Bodrogkeresztúr cultures, cremation was an incidental ritual, which did not lead to a wider propagation of the idea of cremation among societies of the early Copper Age, or those from the beginnings of the middle Copper Age.

It was only at the beginning of the 4th millennium BC, in the Lažňany group, which was occupying the northern part of the Carpathian Basin, that cremation became an important element in the burial ritual (Lichter 2001, fig. 160). From this period come several dozen burials located on four cemeteries:

1. Male Zalužice-Lažňany: 20 graves, including 16 cremation graves (Budinský-Krička 1964, 87-96); 


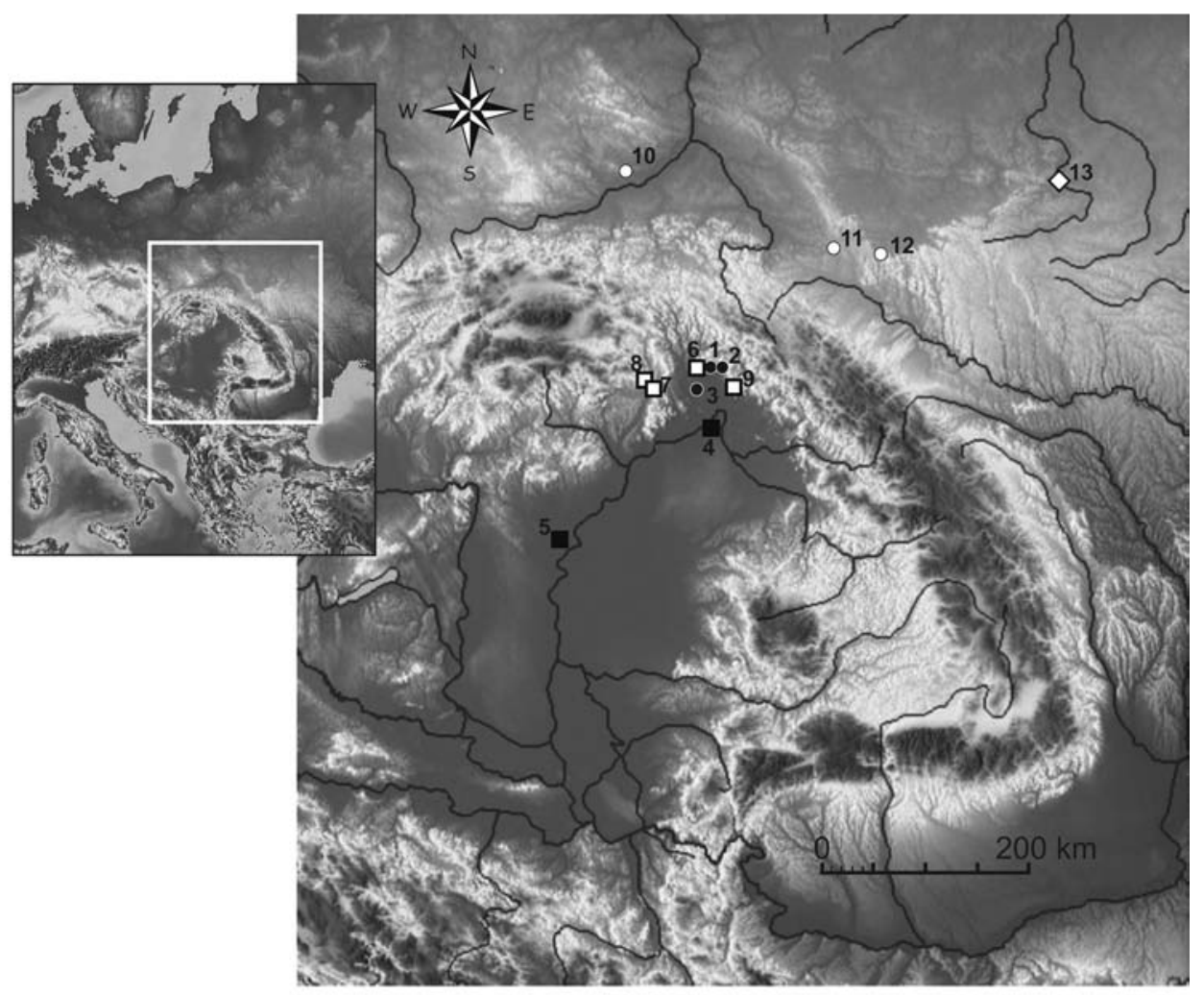

LEGEND

Location of the cemetery with cremation burials:

- - on the Tiszapolgár culture

- on the Bodrogkeresztúr culture

- on the Lažñany group

- on the Lublin-Volhynian culture

$\diamond$ - on the Trypolie culture

\author{
1 - Lúčky, Kosice region, Slovakia \\ 2 - Tibava, Kosice region, Slovakia \\ 3 - Vel'ke Raškovce, Kosice region, Slovakia \\ 4 - Fényeslitke, Szabolcs-Szatmár-Bereg county, Hungary \\ 5 - Jászladány, Jász-Nagykun-Szolnok county, Hungary \\ 6 - Male Zalužice-Lažñany, Kosice region, Slovakia \\ 7 - Šebastovce, Kosice region, Slovakia \\ 8 - Barca, Kosice region, Slovakia \\ 9 - Velykie Lazy, Zakarpattia region, Ukraina \\ 10 - Książnice, świętokrzyskie province, Poland \\ 11 - Gródek, Lviv region, Ukraina \\ 12 - Dźwinogród, Lviv region, Ukraina \\ 13 - Ostróg, Rivne region, Ukraina
}

Fig. 8. Map of the location of cemeteries with cremation burials in the early and middle Copper Age in the

Carpathian Basin and the north edge of the Carpathian Mountains, drawn by S. Wilk based on Lichter 2001; Brummack 2015, on the backing downloaded from https://maps-for-free.com/, (C) autorzy OpenStreetMap)

2. Šebastovce: 42 graves, including 11 cremation graves ( 4 urn burials), 23 skeletal graves, 9 indeterminate graves (Šiška 1972, 110-122);

3. Barca: 27 graves, including 6 cremation burials (3 urn graves), 12 skeletal graves, 9 indeterminate graves (Šiška 1972, 122-128); 
4. Velyke Lazy: cemetery described as a cremation one, but the exact number of graves is not known (Budinský-Krička 1964, 96-99; Nevizansky 1984, 288).

As can be seen from the above data, the percentage of cremation burials in the extreme case reached 80\% (Male Zalužice-Lažňany), and on the cemeteries of Šebastovce and Barca, respectively $26 \%$ and $22 \%$.

The majority of cremation features can be described as pit burials, in whose fill concentrations of burnt human were found. Unfortunately, in most cases, outlines of pits have not been preserved, or have not been documented, and therefore it is difficult to say anything about the size and shape of these features. Burial goods mostly consist of two to three vessels, sometimes accompanied by single flint artefacts (Budinský-Krička 1964, 87-96; Šiška 1972, 111-128). The richest assemblages (graves 23 and 8 from the Šebastovce cemetery) have 7 and 9 vessels, respectively (Šiška 1972, 114-115; Nevizansky 1984, 289). None of the cremation burials yielded copper artefacts. Only 7 cases (graves 1, 3, 5 at Barca cemetery and graves 13, 15, 22 and 26 at Šebastovce cemetery) contained urn burials, and burnt human remains were found inside the vessels (Nevizansky 1984, 288).

Owing to recently published radiocarbon dates of four graves from Barca cemetery, we know that the necropolis functioned in the years 3960-3800 BC (Brummack 2015, fig. 16). Even though these dates were obtained from skeletal graves, until now they are the best reference to the chronology of the cremation graves in the Lažňany group. At the same time, it must be emphasized that very similar dates, going back to the $4^{\text {th }}$ millennium BC, have been obtained for skeletal graves of the Hunyadihalom group, which were discovered in the settlement of Tiszalúc-Sarkad (Brummack 2015, fig. 16; Raczky and Siklósi 2013, table 2).

Traces of cremation were also recorded at several sites of Ludanice group (i.a. Bratislava-Dúbravka, Čierne Klačany, Komjatice, Nevidzany), Balaton-Lasinja I culture (i.a. Nadap, Sémjénháza, Zalaszentgrót-Tekenye) and Bajč-Retz group (Gajary, Hokovce, BratislavaDevínska Nová Ves, Komjatice) in the Transdanubia and West Slovakia (Šuteková 2007, 7).

Within the societies of the Lublin-Volhynia culture, living on the border of Roztocze and the Podolian Upland, we know of two cases of cremation burial ritual. Both are from the area of Lviv. The first one is Dźwinogród, site Hojeva Hora, where a cemetery consisting of four skeletal graves and one cremation burial was discovered (feature 2). Feature 2 covers the area of $c a 75 \times 50 \mathrm{~cm}$. In the southern part of the pit, there were burnt human bones, and among them - a blade, a retouched blade made of Volynian flint and a horn battle axe. While, a small copper hook and a lower part of a vessel were unearthed in the western part of the pit (Sveshnikov 1956, 57). Anna Zakościelna believes that it is the case of a destroyed skeletal grave of the Lublin-Volhynia culture by a younger cremation feature from the Roman period (Zakościelna 2010, 70).

The second case is from the village of Gródek, which is also situated in the district of Lviv, and where - during the building works conducted in the spring of 2014 - a very rich burial was found; it contained, according to accidental discoverers, burnt bones. The burial 
goods consisted of fragmentarily preserved eight clay vessels (semi-spherical bowls, pots and amphorae), and eight copper ornaments (a triangular pendant, five bracelets of various types and two half-rings), some of which had traces of burning (Pawliw et al. 2016).

Of great interest is also the cemetery of the Tripolye culture (phase BII), situated about $200 \mathrm{~km}$ to the east, in Ostróg in the district of Rovno. Its unique character is due to the fact that in its pottery inventory we can observe characteristics of phase BII of the Tripolye culture and of the Rzeszów phase of the Malice culture (Pozikhovkiy and Samolyuk 2008). This necropolis, preliminarily dated to $c a 4100-3600 \mathrm{BC}$, consisted of 18 cremation burials, forming an oval elongated along the N-S axis (Pozikhovkiy and Samolyuk 2008, fig. 1b). Apart from the painted Tripolye culture in the graves, there were many forms characteristic of the Malice culture such as goblets and cups with high, outward- bent necks, as well as bowls and pots with bi-conical profiles, decorated with notched ornaments on shoulders or the spouts (Pozikhovkiy and Samolyuk 2008, 41, fig. 2, 4-9, 11). Among the unearthed objects, particularly noteworthy is a vessel shaped like a flower pot from feature 9, decorated with knobs reaching above the spout, and characteristic of the Lublin-Volhynia culture (Pozikhovkiy and Samolyuk 2008, fig. 6: 2). Unfortunately, like in the case of the other aforementioned cremation features, there are virtually no details concerning the outlines or sizes of the burial pits. Only in the case of grave 18 do we know that it was an oval oriented along the E-W axis, ca 115 x $95 \mathrm{~cm}$ (Pozikhovkiy and Samolyuk 2008, 35, fig. 10).

Among the above presented examples of cremation burials, it is very difficult to point another arrangement of human remains and burial goods like the one discovered in grave 14 in Książnice. It seems that a slightly similar arrangement only occurred in grave 34 from the village of Šebastovce, where two vessels were located south of a concentration of burnt bones (Šiška 1972, abb. 17: 34).

\section{SUMMARY}

The discovery of the cremation grave at the cemetery of the Lublin-Volhynia culture at site 2 in Książnice sheds new light on the complicated processes of the adaptation of southern cultural patterns by societies living in Lesser Poland at the turn of the $5^{\text {th }}$ and $4^{\text {th }}$ millennium BC. To date, it has been thought that in the discussed period, north of the Carpathians, there was only one type of burial - namely, inhumation, and new socio-cultural trends were reduced to the acceptance of most norms of conduct in relation to the deceased, such as creating separate cemeteries at some distance from settlements, and diversification of burials depending on the gender and social status of the buried individual.

Most researchers, while describing the changes that occurred in the social structure, sepulchral customs and material culture of the groups living in Lesser Poland in the second half of the $5^{\text {th }}$ and $4^{\text {th }}$ millennium BC, highlight the significance of the influences from older groups of the Polgar cycle (such cultures as the Tiszapolgár and Bodrogkeresztúr 
cultures; Kozłowski 1971; 2006; Kadrow 2008; Zakościelna 2010). Meanwhile, in light of the new data presented above about the absolute chronology of the Copper Age in the Carpathina Basin and the new materials of the Lublin-Volhynia culture from Pińczów Hummock (Książnice) and the borderland between Roztocze and Podolian Upland (Gródek), it turns out that societies of the Hunyadihalom-Lažňany horizon could have played a much greater role than previously thought in changing the cultural face of the areas located on the northern and north-eastern foreland of the Carpathians (Wilk 2016, 23).

\section{Acknowledgements}

We would like to express our gratitude to Anna Zakościelna and Jerzy Libera for helping with the excavation research at site 2 in Książnice in August 2012, and to Jerzy Libera for the description and drawing of flint artifacts from the grave 14. We would also like to thank Danuta Makowicz-Poliszot for the animal bone analysis.

The archaeological excavations at site 2 in Książnice in August 2012 were funded by the Voivodeship Monuments Protection Office in Kielce.

\section{References}

Brummack S. and Diaconescu D. 2014. A Bayesian approach to the AMS dates for the Copper Age in the Great Hungarian Plain. Praehistorische Zeitschrift 89, 242-260.

Brummack S. 2015. New Radiocarbon Dates from Eastern Slovakia. The cases of Malé Raškovce and Barca Baloty. In S. Hansen, P. Raczky A. Anders and A. Reingruber (eds.), Neolithic and copper Age between the Carpathians and the Aegean Sea. Chronologies and Technologies from the $6^{\text {th }}$ to $4^{\text {th }}$ Millennium BC. International Workshop Budapest 2012 (= Archäologie in Eurasien 31). Bonn: Rudolf Habelt, 1-19.

Budinský-Krička V. 1964. Pohrebisko z neskorej doby kamennej w Malých Zalužiciach - Lažnaňoch. Študijné Zvesti Archeologického Ústavu Slovenskej Akadémie Vied 13, 87-110.

Czekaj-Zastawny A. (ed.) 2009. Obrzqdek pogrzebowy kultur pochodzenia naddunajskiego $w$ neolicie Polski poludniowo-wschodniej (560o/550o-29oo BC) / The funerary rite of the Danubian Cultures in the Ne olithic of southeastern Poland (560o/550o-290o BC). Kraków: Instytut Archeologii i Etnologii Polskiej Akademii Nauk.

Fairgrieve S. I. 2008. Forensic Cremation. Recovery and Analysis. Boca Raton, FL: CRC Press.

Furmanek M. and Mozgała-Swacha M. 2017. Chronologia absolutna cmentarzyska kultury jordanowskiej w Domasławiu. In B. Gediga (ed.), Archeologiczne Zeszyty Autostradowe 19. Badania na autostradzie A-4 14. Wrocław: Instytut Archeologii i Etnologii Polskiej Akademii Nauk, 179-196.

Gil-Drozd A. 2011. The Origins of Cremation in Europe. Analecta Archaeologica Ressoviensia 5, 9-94. Gruszczyńska A. and Mitura P. 2002. Materiały kultury lubelsko-wołyńskiej w rejonie Księżych Górek w Łańcucie. Materiały i Sprawozdania Rzeszowskiego Ośrodka Archeologicznego 23, 33-53. 
Grygiel R. 2008. Neolit i początki epoki brąu w rejonie Brześcia Kujawskiego i Osłonek 2. Środkowy neolit. Grupa brzesko-kujawska kultury lendzielskiej. Łodź: Fundacja Badań Archeologicznych Imienia Profesora Konrada Jażdżewskiego - Muzeum Archeologiczne i Etnograficzne w Łodzi.

Kadrow S. 1989. Materiały kultury lubelsko-wołyńskiej ze stanowiska nr 1D w Strzyżowie, woj. zamojskie, z badań 1961-63. Prace i Materiaty Zamojskie 2, 5-33.

Kadrow S. 2008. Gender-differentiated burial rites in Europe of the $5^{\text {th }}$ and 4 th millennia BC: attempts at traditional archaeological interpretation. Analecta Archaeologica Ressoviensia 3, 49-95.

Gediga B., Mozgała M. and Murzyński T. 2012. Nowe źródła do poznania grupy jordanowsko-śląskiej. In J. Juchelka (ed.), Archeologicky sbornik $k$ šedesatym narozeninam Vratislava Janaka. Opava: Slezska Univerzita, 74-86.

Gruszczyńska A. and Mitura P. 2002. Materiały kultury lubelsko-wołyńskiej w rejonie Księżych Górek w Łańcucie. Materiały i Sprawozdania Rzeszowskiego Ośrodka Archeologicznego 23, 33-53.

Gurba J. and Kutyłowski A. 1970. Sépulture ŕ inhumation No 3, 4, 5 Strzyżów 2 A, distr. de Hrubieszów. Inventaria Archaeologica (Pologne) 25, 151-153.

Kaczanowska M. 2009. Obrządek pogrzebowy w kulturze lendzielskiej. In A. Czekaj-Zastawny (ed.), Obrzadek pogrzebowy kultur pochodzenia naddunajskiego $w$ neolicie Polski południowo-wschodniej (560o/550o-290o BC). Kraków: Instytut Archeologii i Etnologii Polskiej Akademii Nauk, 67-105.

Kadrow S. and Kłosińska E. 1989. Obiekt kultury lubelsko-wołyńskiej na stanowisku 10 w Łańcucie, woj. rzeszowskie. Sprawozdania Archeologiczne 40, 9-25.

Kadrow S. and Zakościelna A. 2000. An outline of the evolution of Danubian cultures in Małopolska and Western Ukraine. In A. Kośko (ed.), The Western Border Area of the Tripolye Culture (=Baltic-Pontic Studies 9). Poznań: Institute of Prehistory Adam Mickiewicz University, 187-255.

Kempisty E. 1962. Grób kultury wstęgowej ceramiki malowanej w Werbkowicach, pow. Hrubieszów. Wiadomości Archeologiczne 28, 198-200.

Kośko A. and Videiko M. Y. 1995. Origins of neolithic-eneolithic cremation rites in Europe and Sofievka type rituals. In A. Kośko (ed.), Cemeteries of the Sofievka type: 2950-275o BC (= Baltic-Pontic Studies 3). Poznań: Institute of Prehistory Adam Mickiewicz University, 247-258.

Kowalczyk J. 1950. Drugi grób kultury wstęgowej ceramiki malowanej z Jaszczowa, w pow. lubelskim. Annales Universitatis Mariae Curie-Skłodowska. Sectio F, Nauki Filozoficzne i Humanistyczne 5, 1-7.

Kozłowski J. K. 1971. Eneolityczne groby szkieletowe z Nowej Huty-Wyciąża. Materiały Starożytne i Wczesnośredniowieczne 1, 65-97.

Kozłowski J. K. 2006. Grupa Wyciąże-Złotniki i bezpośrednie oddziaływania późnopolgarskie. In M. Kaczanowska (ed.), Dziedzictwo cywilizacji naddunajskich: Matopolska na przetomie epoki kamienia i miedzi. Kraków: Muzeum Archeologiczne w Krakowie, 53-62.

Kruk J. and Milisauskas S. 1985. Bronocice. Osiedle obronne ludności kultury lubelsko-wohyńskiej (280o-270o lat p.n.e.). Wrocław: Ossolineum. 
Lichter C. 2001. Untersuchungen zu den Bestattungssitten des sudeuropaischen Neolithikums und Chalkolithikums (= Heidelberger Akademie der Wissenschaften. Internationale Interakademische Kommission fur die Erforschung der Vorgeschichte des Balkans 5). Mainz am Rhein: Verlag Philipp von Zabern.

McKinley J. I. 1994. Bone Fragment Size in British Cremation Burials and its Implications for Pyre Technology and Ritual. Journal of Archaeological Science 21, 339-342.

Nevizansky G. 1984. Sozialökonomische Verhältnisse in der Polgár-Kultur Aufgrund der Gräberfeldanalyse. Slovenska archeologia 32(2), 263-310.

Nowak M. 2014. Późny etap rozwoju cyklu lendzielsko-polgarskiego w zachodniej Małopolsce. In K. Czarniak, J. Kolenda and M. Markiewicz (eds.), Szkice neolityczne. Księga poświęcona pamięci prof. dr hab. Anny Kulczyckiej-Leciejewiczowej. Wrocław: Instytut Archeologii i Etnologii Polskiej Akademii Nauk, 239-284.

Patay P. 2005. Kupferzeitliche Siedlung von Tiszalúc. Budapest: Magyar Nemzeti Múzeum.

Pawliw D., Petehyrycz W., Konopla W. and Wojcieszczuk N. 2016. Bogaty grób kultury lubelsko-wołyńskiej z Gródka w obwodzie lwowskim. In A. Zakościelna (ed.), XXXII Konferencja Sprawozdawcza Badania archeologiczne w Polsce środkowowschodniej, zachodniej Biatorusi i Ukrainie w roku 2015. Streszczenia wystapień. Lublin: Instytut Archeologii UMCS w Lublinie, Muzeum Lubelskie w Lublinie, 8-9.

Piontek J. 1976. Proces kremacji i jego wpływ na morfologię kości w świetle wyników badań eksperymentalnych. Archeologia Polski 21(2), 247-280.

Piontek J. 2002. Wpływ procesu kremacji na morfologię kości szkieletu ludzkiego. Wyniki badań eksperymentalnych. In J. Wrzesiński (ed.), Popiót i kość. Funeralia Lednickie 4, 95-108.

Pozikhovskiy O. L. and Samolyuk V, O. 2008. Eneolitychniy krematsiyniy mogilnik v okolitsakh Ostroga na Zakhidniy Volinii. Arkheologiya 2008(1), 28-41.

Raczky P. and Siklósi Zs. 2013. Reconsideration of the Copper Age chronology of the eastern Carpathian Basin: a Bayesian approach. Antiquity 87, 555-573.

Sałacińska B. and Zakościelna A. 2007. Pierwsze groby kultur ceramik wstęgowych w Polsce (Groby kultury lubelsko-wołyńskiej ze stanowiska Złota „Grodzisko I i II”). Wiadomości Archeologiczne 59, 77-113.

Seger H. 1906. Die Steinzeit in Schlesien. Archiv für Anthropologie. NF 5, 116-141.

Šiška S. 1964. Pohrebisko tiszapolgárskej kultúry v Tibave. Slovenská archeologia 12/2, 293-356.

Šiška S. 1972. Gräberfelder der Lažňany-Gruppe in der Slowakei. Slovenská archeologia 20, 107-175.

Šuteková J. 2007. Príspevok k problematike žiarového pohrebného rítu v období neolitu a eneolitu. Zborník Filozofickej fakulty Univerzity Komenského. Musaica 25, 5-13.

Sveshnikov I. K. 1956. Mogilnik v sele Zvenigorod Lvovskoy oblasti. Kratkiye Soobshchenya Instituta Materialnoy Kultury 63, 57-68.

Wilk S. 2004. Graves of the Lublin-Volhynian culture at site 2 in Książnice, district of Busko Zdrój. 2001/2002, 2003 exploration seasons. Sprawozdania Archeologiczne 56, 223-270.

Wilk S. 2006. Graves of the Lublin-Volhynian culture at site 2 in Książnice, district of Busko Zdrój. 2004 exploration season. Sprawozdania Archeologiczne 58, 247-273. 
Wilk S. 2014. An elite burial from the Copper Age: Grave 8 at the cemetery of the Lublin-Volhynian culture at Site 2 in Książnice, the Świętokrzyskie province. Analecta Archaeologica Ressoviensia 9, 209-243.

Wilk S. 2016. New data about chronology of the impact of the Hunyadihalom-Lažňany horizon on Younger Danubian cultures north of the Carpathian Mountains. Recherches Archéologiques, Nouvelle Serie 7, 7-28.

Wilk S. and Kufel-Diakowska B. 2016. The Lublin-Volhynian culture retouched blade daggers in light of usewear analysis of artefacts from burials at site 2 in Książnice, Poland. Archaeologia Polona 54, 137-151.

Vizdal J. 1977. Tiszapolgárske pohrebisko vo Vel'kých Raškovciach. Košice: Vyìchodoslovenskè̀ vydavatelstvo.

Zakościelna A. 2006. Kultura lubelsko-wołyńska. Zagadnienia jej genezy, periodyzacji i chronologii. In M. Kaczanowska (ed.), Dziedzictwo cywilizacji naddunajskich: Małopolska na przełomie epoki kamienia i miedzi. Kraków: Muzeum Archeologiczne w Krakowie, 77-94.

Zakościelna A. 2010. Studium obrzq̨dku pogrzebowego kultury lubelsko-wołyńskiej. Lublin: Wydawnictwo Uniwersytetu Marii Curie-Skłodowskiej.

Zawiślak P. 2013. Obiekty neolityczne ze stanowiska 1C w Grodku, pow. Hrubieszów (z badań w latach 1983-1985 Sławomira Jastrzębskiego). In A. Pozikhovski, J. Rogoziński and M. Rybicka (eds.), Na pograniczu kultury pucharów lejkowatych i kultury trypolskiej (= Collectio Archaeologica Ressoviensis 26). Rzeszów: Instytut Archeologii UR, 109-214. 
